\title{
Russian English and what it is not
}

\author{
Alexandra A. RIVLINA \\ National Research University Higher School of Economics \\ Moscow, Russia
}

\begin{abstract}
The arguments against the Expanding Circle (EC) Englishes being varieties in their own right are often provoked by terminological inaccuracies both in professional and folk-linguistic debate. The aim of the article is to particularize the concept of Russian English by highlighting the differences between Russian English as an EC variety per se and a number of English-related forms and practices in Russian-based intranational communication, which also might be referred to as Russian English or Rus(s)lish/Runglish. The article discusses the notion of Ruslish in detail, drawing on the recent surveys of "hybrid Englishes," or "X-lishes" in World Englishes theory. The study provides a qualitative analysis of a corpus of examples illustrating different conceptualizations of Ruslish and some of its major tokens. As a result, Ruslish in the narrow sense of the term, as the basilectal subvariety of Russian English, is distinguished from Ruslish as a broader language-contact concept embracing various cases of English-Russian interaction, primarily the Englishization of Russian, which is closer to its folk metalinguistic interpretation. A special emphasis is placed on the cases of "mock Russian English/Ruslish," a form of bilingual language play, a linguistic parody, when distinctive features of Russian English or Ruslish are exaggerated and ironically quoted in "styling the Other." The article also follows the translanguaging approach to hybrid Englishes investigation and some emergent practices of translanguaging in written English-Russian interaction, specifically some cases of Roman-Cyrillic "trans-scripting," or "tranßcripting", are tentatively defined as "new Ruslish."
\end{abstract}

Keywords: World Englishes, Russian English, Rus(s)lish (Runglish), mock language, translanguaging

\section{For citation:}

Rivlina, Alexandra A. 2020. Russian English and what it is not. Russian Journal of Linguistics 24 (3). 649-668. DOI: 10.22363/2687-0088-2020-24-3-649-668

Научная статья

\section{Русский английский и то, чем он не является}

\section{А.А. РИВЛИНА}

Национальный исследовательский университет «Высшая школа экономики» Москва, Россия

\section{Аннотация}

Аргументы, на основании которых оспаривается самостоятельный статус вариантов английского языка Расширяющегося круга, зачастую обусловлены терминологическими неточностями как в профессиональных, так и в любительских лингвистических дискуссиях. Цель 
статьи - уточнить понятие русского варианта английского языка через сопоставление его с теми языковыми формами и практиками в русскоязычной внутринациональной коммуникации, которые связаны с английским языком и тоже иногда определяются как «русский английский» или «руслиш/рунглиш», но отличаются от русского английского как варианта Расширяющегося круга. В статье подробно анализируется понятие «руслиш» на основе недавних исследований так называемых «гибридных английских» или «Х-лишей» в теории контактной вариантологии английского языка. Исследование представляет собой описание корпуса примеров различных концептуальных пониманий руслиша и его основных маркеров. В результате становится возможным разграничить руслиш в узком понимании этого термина, в качестве базилектного подварианта русского английского, и в широком понимании, которое более характерно для обыденного метаязыкового сознания и подразумевает различные типы взаимодействия русского языка с английским, в первую очередь англизацию русского языка. Особое внимание в статье уделено шутливо-пародийному русскому английскому, одной из форм билингвальной языковой игры, языковой пародии, при которой дистинктивные признаки русского варианта английского языка и руслиша иронически преувеличиваются и воспроизводятся в процессе «стилизации Другого». Кроме того, в статье используется транслингвальный подход к описанию «гибридных английских», в соответствии с которым все более заметные транслингвальные практики в письменном взаимодействии русского и английского языков, в частности, «транскриптализм» во взаимодействии кириллицы и латиницы, предлагается рассматривать как проявления «нового руслиша».

Ключевые слова: контактные варианты английского языка, русский английский, руслии (рунглиш), пародийный язык, транслингвизм

\section{Для цитирования:}

Rivlina A.A. Russian English and what it is not. Russian Journal of Linguistics. 2020. Vol. 24. № 3. P. 649-668. DOI: 10.22363/2687-0088-2020-24-3-649-668

\section{Introduction}

The status of Expanding Circle (EC) Englishes alongside the Inner Circle (IC) and Outer Circle (OC) English varieties is "a thorny subject of incessant metalinguistic and sociolinguistic discussions" (Proshina 2019: 233) in both professional and lay debate. One of the major sources of disagreements on this issue lies in the intransigent metalinguistic beliefs and attitudes of "folk linguists" (Niedzielski \& Preston 2000), whose perception of EC varieties such as Russian English cannot but influence professional linguistic discourse.

Similar to other EC countries, the majority of Russian speakers tend to discuss a number of English-related forms and practices, especially those which are frowned upon in Russian-speaking society, under the rubric of "Ruslish" ("Russlish," "Runglish," etc.). ${ }^{1}$ When the term "Russian English" is used, it is often equated with Ruslish.

${ }^{1}$ In his thorough investigation of different "lishes," Lambert (2018: 30) has enumerated and estimated the frequency of a dozen of "Russian + English" portmanteau terms, including the most frequent ones, "Russlish" and "Runglish", and some rare ones, such as "Ringlish" or "Rublish." Epstein (2006) insists that "Russlish" is the only correct term, mainly because it was the first one introduced into English in Arthur C. Clarke's novel "2010: Odyssey Two." A small subplot in the book concerned a Stamp Out Russlish! campaign aboard a Russian-American spaceship. In this article, "Ruslish" is employed as the term most widely used in World Englishes publications. 
The aim of this article is to particularize the concept of Russian English by highlighting the differences between Russian English as an EC variety per se and a number of English-related contact-induced phenomena which might be also referred to as Russian English or Ruslish in certain contexts, primarily in folk linguistics. First, the notion of Ruslish will be discussed in detail drawing on recent surveys of "hybrid Englishes," or "lishes" in World Englishes theory. Next, a special focus will be made on the cases when distinctive features of Russian English or Ruslish are exaggerated and played on. These cases are described in terms of "styling the Other" and "mock language" research. It is argued that "mock Russian English/Ruslish" should not be confused with Russian English as an actual variety: "mock Russian English/Ruslish" is a form of bilingual language play, a linguistic parody, which implicitly testifies to Russian speakers' increasing awareness of Russian English, but is in many critical ways different from it.

Finally, this article tackles the controversies in Russian English investigation through the perspective of translanguaging, one of the most significant current trends in sociolinguistics of globalization and multilingualism research. Translanguaging refers to fuzzy and fluid "discursive practices that cannot be easily assigned to one or another traditional definition of language" (García \& Li 2014: 22). In recent studies, translingual use of English language resources by local language speakers in EC countries is sometimes interpreted as "new X-lishes," for instance, "new Chinglish" (Li 2016, Xu \& Deterding 2017). This article will discuss some emergent practices of translanguaging in written English-Russian interaction that are tentatively termed "new Ruslish."

\section{EC Englishes and linguistic hybridity research}

Proshina (2019) highlights that the arguments against EC Englishes being varieties in their own right are often based on terminological misconceptions and inaccuracies. In most cases, confusion is caused when EC varieties, actually performed by speakers of local languages when using English, are equated with the following:

— with the "model" (input) of English teaching and learning, which in EC contexts is based on British or American varieties norms, or on the abstract model of English as an International Language (EIL);

- with English as a Lingua Franca (ELF), which is not a variety characterized by certain distinctive features, but a function, or an activity mode in intercultural communication; or,

— with so-called "learner English" or with learner's "interlanguage," which are psycholinguistic concepts dealing with an individual's language state.

Overall, different conceptualizations of Englishes do not exclude each other, but rather overlap and complement each other, reflecting the increasingly diversifying English uses worldwide from different angles. The complexity of these multifarious language phenomena generates the analytical complexity and a 
number of terminological confusions have to be disentangled before EC Englishes are granted or denied the status of a language variety.

One of the misconceptions leading to terminological mix-up in Russian English research is connected with the notion of Ruslish. In the World Englishes theory, each variety is treated as a sociolinguistic bilingual cline, a continuum of functional zones called "lects" - acrolect, mesolect, and basilect - based on different levels of English proficiency from the highest to the lowest. Russian English as a variety embraces all three functional zones. On this cline, the distinctive features are particularly manifest at the mesolectal level, which is therefore referred to as Russian English in the narrow sense of the term (see the summary in Proshina 2020, Proshina \& Eddy 2016: 81-120). Within this framework, the term "Ruslish" is related to learners' deficient English, that is, to basilectal performance of English by less proficient Russian speakers (Proshina 2020: 242, Proshina \& Eddy 2016: 26-27).

Basilectal performance of local English speakers is the primary meaning of similar portmanteau terms built on the formula "X [language name] + English," known as "Anglo-hybrids," "hybrid Englishes," "X-Englishes," or just "lishes" (Schneider 2016, Lambert 2018). ${ }^{2}$ In public discourse, such hybrids are usually stigmatized as "broken English." However, a basilectal local version of English is not the only sense in which various "X-lish" terms are used, especially in folklinguistic discussions in different countries. For example, Lambert (2018: 7) summarizes quite a number of various characterizations of Japlish (Janglish, Jangrish, etc.). Some of them exhibit the idea of Japlish as the negatively assessed basilectal sub-variety of Japan(ese) English - "poor English," "a stilted Japanese version of English," "bastardized English" - while others expand it to all "English as spoken by Japanese" or, vice versa, narrow it down to specific Japanese-English contact results, such as "Japanese-coined English phrases," "the invasion of Japan by English words," "weird translational malapropisms," "a hybrid grammar introducing English components to standard Japanese, or Japanese components to standard English," "Japanese words spelled out in English," or "English written in katakana." As Lambert comments, "[1]eaving the abundance of negativity aside for the time being, in aggregate these attempts at definition speak to the multitude of linguistic phenomena characteristic of language hybridity in multilingual settings, albeit explained with differing emphases by different definers" (Lambert 2018: 7).

There have been attempts to streamline a host of interpretations of X-lishes and to distinguish them terminologically. One of the approaches is to suggest different terms to separate the two directions of English-vernacular interaction. D'Souza (2001: 9-11) writes about Hinglish A, which she describes as a variety of Hindi with English as a source for lexical borrowing, and Hinglish B, which is, vice versa,

${ }^{2}$ Besides "X [language name] + English," other less common blend patterns may be used for various language combinations, such as franglais in France or Sheng in Kenya (see the survey in Schneider 2016 and Lambert 2018). In Russia, other terms for Rus(s)lish/Runglish are rusangl ("angl" as in angliiskiy, English) (Marinova 2013: 142) or rungliiskiy (Merkulova 2015: 48). 
a variety of English with Hindi as a source of borrowing. In Greek linguistics, the term Greeklish often refers to Latin-alphabet transliterated Greek, while a different term, "engreek," is introduced for the reverse process, English-related forms written with Greek characters (Androutsopoulos 2015, Spilioti 2019). The term "rusangl," used by some Russian linguists for the overuse of Anglicisms in modern Russian speech (Marinova 2013: 142), may be seen as an attempt to stay away from Ruslish controversies in lay linguistic discussions. On the other hand, Lambert, when highlighting similar terminological pairs in other countries (Spanglish vs. Englanol, Hunglish vs. Engarian, etc.), argues that they "fall into the common definitional trap of being overly precise" (Lambert 2018: 7). X-lishes resist any attempts at neat compartmentalization, first, because in many cases they involve processes of intense mixing that are "not in line any longer with the idea of 'matrix' or 'base' language" (Schneider 2016: 351), and second, because "[w]ere such restricted senses to actually be adopted in the field of linguistics, these might be at odds with wider usage, thus creating nomenclature ambiguity" (Lambert 2018: 9).

It seems to be the case that numerous X-lish definitions, vague and ill-defined as they are, have a common denominator. All X-lishes, including Ruslish, reflect a simplified but powerful linguistic ideology of languages as discreet entities with clear-cut borders between them that need to be upheld (hence, the negative attitude to hybridization). Folk linguists appear to use these terms to refer to a nebulous cluster of linguistic constructs united by such ideology, though in each particular case some manifestations of an X-lish are emphasized while others are overlooked.

Another important distinction, which causes confusion when it is overlooked, is the distinction between Russian English as a variety with Ruslish as its basilect, on the one hand, and on the other hand, language play on Russian English and Ruslish, which may be described as "mock Russian English/Ruslish". The concept of "mock languages" was developed in linguistic anthropology to describe the practice of exaggerating and spoofing the stereotypical linguistic features of speakers of other languages in order to create a jocular or pejorative effect. In English-speaking contexts, "mock languages" overlap with X-lishes, revealing similar hybridized forms and practices. For example, incorporated into Englishbased American discourse, "mock Spanish" implies either playful "hypervernacularization" of English, for instance, el cheap-o for "cheap" (Spanish morphology mixed with English vocabulary), or "hyper-anglicized" ludic representations of vernacular lingual units, for instance, a double entendre grassyass for gracias, "thank you" (Hill 1998: 682). Despite similarities in linguistic techniques, the mixture of Spanish and English in "mock Spanish" is in most cases different from Spanglish, and Spanish speakers themselves would not use most of such "mock Spanish" tokens when speaking English.

From the point of view of linguistics, "mock language" is not a linguistic variety but linguistic parody based on "speaking from behind a verbal mask" (Zemskaia et al 1994: 180), "styling the Other" (Hill 1999), or "performing the Other" (Pennycook 2003: 515). It foregrounds and alienates some linguistic 
features of a particular community in order to reveal the parodists' attitudes to its members, "distributed along a continuum between aggression and mocking to playful appropriation to heartfelt identification" (Hill 1999: 547).

"Mock language" is most visible when performed by professional comedians and impressionists. Different varieties of English being mocked in comic shows are tackled in a number of publications: see, for example, Crystal (2003: 410) on "variety humour" in English, Moody (2009: 190-194) and Moody \& Matzumoto (2012) on special English language entertainment genres and shows in Japan, or Chun (2004) on "mock Asian" of American comedians mimicking Chinese, Korean, and Japanese speakers of English. At the same time, like all the other types of bilingual creativity and language play, "mock language" is often employed to contribute to "everyday creativity" in regular informal communication.

The theorizing of English varieties is further complicated due to some emergent discursive practices triggered by the English language globalization and defined in modern sociolinguistics as "translanguaging" (Canagarajah 2013, García $\& \mathrm{Li}$ 2014). It implies that various English-related linguistic resources are increasingly often employed by people all over the world not as part of an autonomous foreign language system, but as part of their own fluid "linguistic repertoire with features that have been societally constructed as belonging to two separate languages" (García \& Li 2014: 2). The globalization of English has generated an upsurge in English-related linguistic fluidity in EC communities and some researchers describe the manifestations of the translingual use of English language resources by local language speakers in EC countries as "new X-lishes," for instance, "new Chinglish" (Li 2016, Xu \& Deterding 2017).

Especially noticeable are English-related translingual practices blurring the distinctions between English and local languages in writing, because the globalization of English along with the expansion of computer-mediated communication has resulted in global English-local digraphia, or biscriptalism. It means that speakers of local languages, even if they are not proficient in English, master the Roman script associated with English in addition to their local script and broker this resource without switching into English (Androutsopoulos 2012, Rivlina 2016). The products of such biscriptal practices cannot be easily assigned to either the local language or English, and they do not comply with the established features of local English varieties. Thus, these practices are interpreted as "scriptfocused translanguaging," "trans-scripting" (Androutsopoulos 2015: 188), or "tranßcripting" (Li \& Zhu 2019). It should be stressed that trans-scripting and translanguaging in general are not new sociolinguistic phenomena, but "[r]ecent forms of globalization have given more visibility to such forms of communication" (Canagarajah 2013: 2).

As for the study of language varieties, the researchers of translanguaging underline that their practice-based perspective does not mean that other competing constructs should be disregarded (Canagarajah 2013: 27). In other words, the increase in fluidity and fuzziness in linguistic practices due to the globalization of 
English does not undermine "the continuing validity of separate languages" (Jaspers \& Madsen 2016: 246). As Creese and Blackledge put it (2011: 1196), the sociolinguistic position of translanguaging, or "flexible bilingualism," which views language as fluid and changing, with permeable boundaries, coexists with the position of "separate bilingualism," acknowledging language as a social construct which demarcates and reifies identities. Neither of the approaches is to be discarded as they reflect complex realities and different needs of multilingual speakers in different circumstances. Nor, for that matter, should the construct of local English varieties be fundamentally challenged by a translingual approach. What it means in the changing practical and theoretical climate, as language forms transcend national and territorial boundaries, is that "a monodimensional, static listing of reified varieties" is no longer acceptable (Onysko 2016: 198-199). All English varieties, including EC varieties and Russian English among them, should be seen as "fuzzy and prototypical categories" (Onysko 2016: 215), with a lot of fluidity, flexibility, and overlap between them and other contact phenomena.

\section{Data and methodology}

This article is part of an ongoing investigation of the Englishization of Russian over a period of more than fifteen years. Some of the issues pertaining to EnglishRussian contact phenomena which are dealt with here have been discussed separately in the author's previous research; see, for example, bilingual language play in (Rivlina 2015, Rivlina 2020), "mock Russian English/Ruslish" in (Proshina \& Rivlina 2018), or translanguaging in Roman-Cyrillic interaction in (Rivlina 2016, Rivlina 2017). Most of the examples in this article have been culled from the corpora collected for those publications. In addition, a small-scale informal study using Internet search engines (Google and Yandex) and the Russian National Corpus (RNC) has been carried out for this article to illustrate the use of the key terms "Russian English" and "Rus(s)lish/Runglish," and some of the Ruslish token forms in Russian-based discourse. The videos addressed in the "mock Russian English" part of this article were discussed in the author's presentations at the conferences of the International Association for World Englishes (IAWE) in 2017 and 2018, and the Internet links to them were re-accessed and confirmed in December 2019.

\section{Ruslish among other hybrid Englishes}

In Outer and Expanding Circle countries, people typically voice their understanding of $\mathrm{X}$-lishes by pointing to a symbolic public figure who epitomizes the heavily accented, error-ridden and embarrassingly hybridized local English subvariety. Their English speech idiosyncrasies become the tokens of national "lishes." For example, as Alison Edwards states in her interview (Nicholls-Lee 2018), "[p]opular culture has made a folk devil of football manager Louis van Gaal and his bewildering Dutch-English." In Edward's opinion, van Gaal's English is 
perfectly functional and far from basilectal, however, many people see it as Dunglish because of his pronounced Dutch accent and his penchant for literal translations of Dutch idioms into English (Woolcot 2015), a feature which is regarded as a basilectal deficiency.

In Russia, as commonly agreed and registered both in academic and numerous non-academic publications, the then Minister of Sport Vitaly Leontyevich Mutko came to prominence as a symbolic Ruslish figure in 2010, when he gave a prepared speech starting with the words Let's mi spik from may khart, in Inglish during the bidding process for the 2018 FIFA World Cup. This phrase, pronounced in a strong Russian accent, immediately became an Internet meme and a token of Ruslish. In addition to the accent, it has been mocked for a typical English-learner mistake the substitution of the construction let somebody do something by let's do something. This substitution may be described in terms of interlanguage theory as a fossilized English learner mistake caused by overgeneralization and transfer of training (Tarone 2018: 2-3), because English learners acquire the latter (let's sing, let's read) earlier than the former. An article in the Moscow Times (Dolgov 2015) explains some of Mutko's other famous quotes that exemplify Ruslish. For example, speaking to reporters in Switzerland in 2015, he mixed up English and Russian words to produce the following: Criminality? No criminality... Tomorrow? Nu ... tomorrow meeting budet yevro association. Mozhet budet recommendation, nationalization the yevro. This English-Russian mishmash is hard to understand unless you know that $n u$ is a Russian interjection similar to a hesitant "well," budet in Russian means "will be," yevro means "euro," and mozhet means "maybe." Dolgov (2015) comments that Mutko speaks "a version of English that sounds like he learned the language from stereotypical Russian characters in Hollywood movies."

Similarly to other "lishes," Ruslish as a basilectal version of Russian English is not the only understanding of this term. The fact is, there is no universally accepted definition of Ruslish, but rather there are a multitude of definitions with varying emphases, some of which are specific for the Russian-English contact situation and others which are common for X-lishes in general, as outlined above. Since the scope of this article does not allow for a thorough review of all the sources on the issue of Ruslish, it will suffice to note that, to our knowledge, there has been no major research focusing on Ruslish as an object of study, apart from several short publications (such as Ivleva 2005 or Merkulova 2015). In most cases, Ruslish is not addressed specifically, but is mentioned in connection with other linguistic or sociolinguistic phenomena, for example, Russian-English bilingualism, as in (Kabakchi 2015). Moreover, few dictionaries or reference books include Ruslish/Runglish as an entry (Mostitskiy 2012, Pankin \& Filippov 2011: 109). Though there is no shortage of printed media, online media, and other online resources revealing public beliefs about and attitudes to Ruslish in Russia and in other countries (Cole 2010, Epstein 2006, Khudyakova 2018, Kuznetsov 2012, Nikitin 2009, Vorobyevskii 2017, "Ruslish:..." 2016, Wikipedia 2019), these 
sources still wait for an in-depth sociolinguistic analysis. So far, in addition to Ruslish as the basilectal performance of English by less proficient Russian speakers, the cited sources yield the following interpretations:

- Ruslish as Russian-English code-switching and code-mixing in bilingual communication, for example, by International Space Station crews or between employees in international companies in Russia;

- Ruslish as heavily hybridized and pidginized speech of Russian immigrants in English-speaking countries, for example, in the Brighton Beach community in the US;

- Ruslish as typical deficiencies of Russian learners of English, for example, thick Russian accent, mispronunciations of English words under the influence of Russian, and other types of Russian language interference in English;

- Ruslish as English spoken by Russians in general;

- Ruslish as an informal Romanization of Russian, usually following English spelling rules;

- Ruslish as borrowings from English into Russian being erroneously Russianized, mispronounced or misinterpreted; and

- Ruslish as the Englishization of the Russian language, first and foremost, the influx and overuse of Anglicisms in Russian-based communication.

Numerous examples to illustrate each Ruslish categorization are provided in the sources listed above (though neither the list of sources nor the list of categorizations is exhaustive). It should be stressed here that in Russia, the interpretation of Ruslish as the negatively assessed Englishization of Russian due to excessive borrowing from English dominates in public discourse. It is also the only meaning of the term "Ruslish/Runglish" registered in Russian general dictionaries and in the Russian National Corpus (RNC) as of 2019. Compare the following:

руслиш, неол. (русский + инглиш) - русский язык, засоренный чрезмерными заимствованиями из английского (Mostitskiy 2012).

Ruslish, neolog. (Russian + inglish) - the Russian language polluted by an excessive number of borrowings from English;

Интервью, данное на так называемом самим Волковым рунглише (потоком сознания, изложенном на русском языке с постоянным вворачиванием английских словечек и выражений), представляет собой дичайшую смесь оскорблений с клеветой... (RNC).

The interview given in what Volkov himself defines as Runglish (a flow of consciousness presented in Russian abundantly interspersed with English buzzwords and expressions) is an absurd jumble of insult and slander... ${ }^{3}$

Turning back to the main focus of this article, it is obvious that Russian English as an EC variety should be distinguished from Ruslish as a broad concept embracing various cases of Russian-English hybridization or interference summarized above, especially, when it comes to the Englishization of Russian.

\footnotetext{
${ }^{3}$ Translated here and further on by A. Rivlina.
} 
Another point that needs to be discussed concerns the cases when Ruslish is interpreted as all English spoken by Russians. It might be referred to as "Russian English" in popular discourse. This type of Russian English folk interpretation equating it with Ruslish, which makes no difference between Russian English distinctive features and Russian learner English deficiencies (hereafter, Russian English/Ruslish), reflects the same entrenched ideology of "pure" English and "pure" Russian common for all the other Ruslish categorizations. Consider the following examples:

\begin{abstract}
Хорошее произношение еще как нужно! «Русский» английский звучит довольно-таки смешно (RNC).

Proper pronunciation is extremely important! "Russian" English sounds rather ridiculous;

Ruslish - русский английский - язык, на котором говорят очень многие жители нашей страны <..> русский английский просто кажется неестественным и иногда смешным. Ниже приведен текст на русском английском и его перевод на естественный английский, сделанный мной с моими американскими коллегами <...> (Nikitin 2009).

Ruslish, or Russian English, is a language spoken by many Russian citizens $<\ldots>$ Russian English simply does not sound normal and is sometimes ludicrous. See the text below in Russian English and its normal English translation, which I made together with my American colleagues $<\ldots>$.
\end{abstract}

Similar confusion of local English varieties with their respective X-lishes can be found in some academic publications. For example, comparing Runglish with other hybridized Englishes such as Hinglish, Merkulova (2015: 47-48) uses the terms Hinglish and Indian English interchangeably and claims that these varieties are primarily the result of educational problems and the fossilization of Hindispeaking English learner's mistakes. This is used as an argument to deny the existence of Russian English or Ruslish as a variety, because unlike Indian English or Hinglish, it is restricted functionally and is not considered to be a norm in Russia.

There is certainly a huge difference between "true" or "thriving" mixed codes (Schneider 2012: 55) like Hinglish in India or Taglish in the Phillipines and hybridized Englishes in most EC countries such as Russia, which Schneider describes as "ephemeral" X-Englishes (Schneider 2016: 349). He explains that "in the majority of instances these refer to local languages which have undergone heavy lexical borrowing from English rather than stable new varieties" (Schneider 2016: 349). However, be it norm-developing varieties in OC countries like India or norm-dependent, exonormative EC varieties in countries like Russia, it would be wrong to equate local varieties of English with respective hybrid Englishes. They overlap, but exist alongside each other, serving different sociolinguistic and psycholinguistic purposes. For example, many Filipinos today view the Philippine English as elitist and tend to use Taglish as a relatively unmarked type of verbal behavior in casual contexts (Schneider 2016: 345). 
To conclude this section, denying the existence of Russian English as a variety is deeply flawed on a number of grounds from the point of view of modern sociolinguistics and World Englishes theory. One such case is when Russian English is equated with Ruslish. It does not mean, however, that Ruslish is not a linguistic term at all, as some publications argue (Merkulova 2015: 46). It means, firstly, that "folk Ruslish" as a fuzzy broad concept embracing various instances of stigmatized English-Russian hybridization should be separated from a linguistically rigorous interpretation of this term as the basilectal sub-variety of Russian English. And secondly, this issue remains highly controversial because hardly any serious linguistic research has been carried out on Ruslish and many other X-Englishes, though there is a high degree of awareness of their existence and a lot of local discussions (Schneider 2016: 341). Thus, further documentation of Ruslish and its thorough investigation in tandem with Russian English as an EC variety are crucially important.

\section{Russian English and Ruslish vs. "Mock Russian English / Ruslish"}

Since it is an important part of the present-day linguistic situation in Russia, Ruslish is played on and mocked a lot both in the entertainment industry and in everyday Russian-based discourse. For example, the various categorizations of Russian English/Ruslish discussed above are exhibited in a number of sketches of the Comedy Club show on TNT (as of 2018, the sixth most popular Russian TV channel with a predominantly young audience). One recent sketch parodying Ruslish ${ }^{4}$ shows a business meeting in a company, where the managers drive their "normal Russian"-speaking employee crazy by ridiculously overusing Anglicisms, such as саплай-менеджер (supply manager), десижн-мейкеры (decision makers), месседж нашего нейминга (the message of our naming), etc.

Ruslish as "broken English" is mocked in another Comedy Club sketch, ${ }^{5}$ which portrays a presumably American radio-host interviewing a British producer who promotes an Indian pop-singer. They all speak English with exaggerated respective accents, and the host can hardly understand either of his guests. One especially funny part starts when a Russian listener calls the studio and asks questions in heavily accented and highly hybridized Ruslish. It appears that the only two people who understand each other perfectly well are the non-native speakers, the Russian and the Indian. Other sketches in the Russian English entertainment genre include snapshots of typical Russian English/Ruslish deficiencies of simple-minded Russian businessmen trying to communicate in English abroad, ${ }^{6}$ incompetent English language teachers and their students in a Russian classroom, ${ }^{7}$ or under-

\footnotetext{
${ }^{4}$ URL: https://www.youtube.com/watch?time_continue $=23 \& v=j 7 \mathrm{vewLSZ2eg} \&$ feature $=$ emb_logo

${ }^{5}$ URL: https://rutube.ru/video/7c806393a9705797d7e92c4a05493d5d/?pl_id=3131\&pl_ type $=$ tag

${ }^{6}$ URL: https://www.youtube.com/watch? $v=r 3 B 9 I-B p N 3 A \& t=11 \mathrm{~s}$

${ }^{7}$ URL: https://www.youtube.com/watch?v=0RFz0_MPQyw
} 
qualified Russian-English interpreters who are baffled by untranslatable culturespecific Russian lexis, confuse homonymous words, and ludicrously translate Russian idioms word-for-word. ${ }^{8}$

Overall, "mock Ruslish" belongs to a common type of "variety humour" in various EC countries, which aims to stylize and ridicule a locally relevant stereotyped X-English speaker (Lee 2014). When comedians "fake" linguistic incompetence and assume that their audience can discern the mistakes, they identify themselves and the audience as being different from this "ridiculous Other," which creates a positive communicative bond. Moreover, as pointed out in Lee (2014) and Moody \& Matsumoto (2012), local-English-variety entertainment helps the community to relate to often frustrating shared experiences of English learning and to deal with their "language anxieties."

Similar connotations are rendered when Russian English/Ruslish is stylized and mocked in everyday communication in Russian. A number of linguistic strategies are used for this. One of them is when a real or imagined representative of the social group being mocked is "ironically quoted" (Hill 1999: 552). For example, as was mentioned above, some of Vitaly Mutko's attempts at speaking English have become tokens of Ruslish and are nowadays often quoted to allude to Ruslish as "broken English" in a jocular manner. Consider the following examples:

Говорите с акцентом, как Мутко. «Лец ми спик фром май харт». - Акцент остался, его не стесняюсь (RNC).

You speak with an accent, like Mutko. "Lets mi spik from may khart." The accent remains and I'm not ashamed of it;

Хорошие синхронисты в страшном дефиците, даже самые маститые лингвистические вузы не учат художественному переводу. Но стоит ли по этому поводу переживать? Почти все мы способны перекинуться с иностранцами парой слов на английском, и те обязательно поймут, если «спик фром май харт» (Novosyolova 2013).

Good conference interpreters are in an awfully short supply and even the most prestigious linguistic universities offer no courses in belles-letters translation. Should we be concerned about it? Almost each of us is capable of exchanging a couple of words with foreigners in English and there is no doubt they will understand us, if "spik from may khart."

Unlike in Mutko's speech, which is an example of authentic Ruslish, "[lets me] spik from may khart" in the excerpts above is a manifestation of "mock Ruslish," a symbolic quote thrown in jokingly.

It should be noted that this phrase, like most of the other "mock Russian English/Ruslish" tokens in Russian-based writing, is presented in Cyrillic, mimicking Russian accent and stressing the idea that it is not "genuine" English that is inserted or switched into. This practice of English being playfully rendered in non-Roman scripts can also be interpreted as a specific "mock language"

\footnotetext{
${ }^{8}$ URL: http://odnajdi-v-odesse.video.az/de/video/117857/garik-harlamov-timur-batrutdinovi-demis-karibidis-perevodchik-na-formule-1-v-sochi?locale=ru
} 
technique similar to but in many cases different from standard transliteration, normally employed in the process of borrowing. Spilioti (2019: 2) describes such bilingual practices as "written performances," or local script "refashionings," "respellings" of English that allude to spoken stylizations and associated personas. She analyses engreek, Greek-alphabet respelt English against the backdrop of Greek-accented English stylizations for the humorous portrayals of non-fluent learners of English (Spilioti 2019: 5). In Russia, Cyrillic-refashioned English is widely employed to mockingly index Ruslish. For example, the then Prime Minister of Russia Dmitry Medvedev in his jocular birthday post to Vitaly Leontyevich Mutko on the government's official Instragram page in 2015 wrote $" C$ днем рождения, Виталий Леонтьевич! Э нью эра фо зе волд бигэн!» / "Нарру birthday, Vitaly Leontyevich! E new era for ze world began!" (Dolgov 2015).

Another notable "mock language" strategy is aggressive "hypervernacularization" of lexis, or the fabrication of deliberately erroneous loans from English that allegedly mimic typical misunderstandings or mispronunciations of borrowed terms by X-lish speakers. It sometimes results in stylistically opposed loan doublets, a regular loan being used in stylistically neutral contexts and a mock one in jocular or ironic contexts. As for hyper-Russianized mock loans from English, in addition to being just fun, they are used to voice the disapproval by the majority of Russian speakers of the Englishization of the Russian language, of Ruslish as the overuse of Anglicisms, and also in a wider sense, to imply resistance to the globalization and Westernization of the society. An illustrative example of this technique is the "mock Ruslish" loan лyхари (pronounced as /'lu $\left.u^{k} h a r i /\right)$, which is a mock doublet of a stylistically neutral borrowing лакшери ("luxury", pronounced in Russian in a similar way, as $/{ }^{\prime} 1 \Lambda \mathrm{k} \int \partial \mathrm{ri} /$ ). In the case of лухари (lukhari), the word "luxury" is being playfully "misread," reflecting typical Russian English-learner mistakes - confusion of two variants of the English letter $<\mathrm{u}>$ pronounced as $/ \Lambda /$ or $/ \mathrm{u} /$ and confusion of the English letter $<\mathrm{x}>$ with its Russian homograph pronounced as $/{ }^{\mathrm{k}} \mathrm{h} /$. The source of this mock loan was also an Internet video that went viral and became a meme in Russia. ${ }^{9}$ It features two Russian girls presumably returning from an upscale Moscow suburb shopping mall Barvikha Luxury Village. When asked where they are coming from, they ridiculously maim the English name of the place, with "luxury" pronounced as $/ ' l u^{k} h a r i /$. People still disagree if it was real-life footage or a staged performance of Ruslish. Anyway, whether it is just an "ironic quote" of a real Ruslish episode or a deliberate ludic distortion of the word parodying Ruslish, the lexical variant syxapu (lukhari) has been taken in by Russian speakers as a derogatory term for pseudoluxury, the opposite of real "luxury," a pretentious and vulgar imitation of wealthy life-style, a disapproved striving to emulate the Westernized elite. Like many other "mock Ruslish" loans, лухари (lukhari) has triggered a lot of offline and online public discussion (see the survey in Partanenko 2016) and even a hashtag \#лухари

\footnotetext{
${ }^{9}$ URL: https://www.youtube.com/watch?v=21SHisd0U14
} 
on Russian Instagram, where people reveal their understanding of and their attitude to what this word stands for.

Though the object of study in this article is Russian English as an EC variety, it is worth mentioning that Russian English is also a recognizable English variety in Inner Circle (IC) countries, and as such it is also frequently stylized and mocked. However, the repertoire of tokens employed, their sociolinguistic indexicalities and even the terms used to denote this type of "mock language" are drastically different. To begin with, most English speakers are seldom exposed to the Russian language, but they do have "media-fabricated familiarity" (Hill 1999: 552) with numerous Russian characters speaking schematically Russianized English, marked primarily by phonological peculiarities, such as thrilled $/ \mathrm{r} / \mathrm{h} / \mathrm{w} /$ substituted by $/ \mathrm{v} /$, indistinguishable tense and lax vowels, or specific intonation contours. That is why, in folk metalanguage in IC countries, Russian English is referred to by a metonymically expanded term "Russian accent." ${ }^{.10}$ When Russian-accented English is stylized, the "stylized Other" is an imagined Russian speaker. Therefore, it can be described as Anglo-American "mock Russian," or, to be more precise, as "mock Russian English" which is used to index "Russianness" and to allude to various stereotypes associated with it in the IC. "Mock Russian/Russian English" implies a specific set of not only phonological, but also lexical, grammatical, and even some graphic tokens (for instance, Cyrillic graphemes inserted into English words in writing).

As is often the case, these tokens are employed and stereotypes about Russians are revealed most vividly in "mock Russian/Russian English" performances of English-speaking comedians. Trevor Noah, ${ }^{11}$ Rebel Wilson ${ }^{12}$ and many other comic artists mimic Russian English in typical "scary Russian accent" jokes, for example, about deliberately faking a Russian accent to put off unwanted people. Lexically and grammatically, similar to other "mock languages," "mock Russian/Russian English" in IC countries is based on "reductive oversimplification" (Cutler 1999: 439) and general "mock non-standard English" (Fuller 2009: 663). It means that it is limited to a dozen recognizably Russian personal names, such as Ivan or Boris, emblematic borrowings, such as nyet or comrade, and some random violations of English grammar. For example, a famous comparethemarket.com advertisement campaign features Russian animated meerkat characters speaking Russian-accented English, ${ }^{13}$ however, their slogan "Simples!" and some other allegedly Russian-influenced linguistic features have

${ }^{10}$ The term "accent" is regularly used in folk linguistics to define various English varieties and "mock languages"; for example, Chun writes about "an imagined variety of American English frequently referred to as a 'Chinese accent"' (Chun 2004: 263).

${ }^{11}$ URL: https://www.youtube.com/watch?v=85VHW86GHG8; http://scrapsfromtheloft.com/ 2017/04/22/trevor-noah-afraid-dark-2017-full-transcript/

12 URL: https://www.cheatsheet.com/entertainment/why-rebel-wilson-often-uses-a-russianaccent-in-real-life.html/

${ }^{13}$ URL: https://www.bglgroup.co.uk/businesses-and-brands/compare-the-market 
little to do with the distinctive features of authentic Russian English as described in Proshina \& Eddy (2016) or Proshina (2020).

For further discussion of "mock Russian/Russian English" in IC contexts, "mock Russian English/Ruslish" in Russia, and "mock Englishes" in general, see Proshina \& Rivlina (2018), Rivlina (2015: 448-449), and Rivlina (2020: 417-418). Overall, this type of bilingual language play testifies to speakers' awareness of the distinctive features of local Englishes and X-lishes; however, it needs to be distinguished from actual bilingual communication and varieties of English, such as Russian English.

\section{Translingual English-related forms and practices: "New Ruslish"?}

Finally, a few words need to be said about Russian speakers' translingual use of English language resources, which, similar to "new Chinglish" in China, can be described as "new Ruslish."

"New Ruslish" is primarily evident in English-Russian translanguaging in writing, namely, in Roman-Cyrillic trans-scripting. Regarding such practices, Angermeyer (2012) analyzes what he calls "bivalent," or "ambivalent" written elements employed by Russian immigrant communities in advertisements and automobile-number plates in the US. Russian speakers creatively manipulate the overlap in Roman and Cyrillic scripts to spell English-Russian cognates so that the form could be read in both alphabets, but in either case, the reader would be required to draw on the other alphabet for its interpretation. For example, one such bivalent form ADBOKAT, which represents the Russian word "адвокат" (advokat, "attorney", correlating with its English cognate advocate), makes use of a Cyrillic reading of the shared letter $\langle\mathrm{B}>$, pronounced in Russian as $/ \mathrm{v} /$, and includes the letter $<\mathrm{D}>$ that is not shared, but resembles the cursive variant of the Cyrillic letter $<Д>-<D>$ (Angermeyer 2012: 265).

A number of Roman-Cyrillic bivalent or translingual written forms in intranational communication in Russia, specifically in modern Russian linguistic landscape and in the Internet domain names, are discussed in Rivlina (2017). Some of them are stylistically neutral. For example, the site name transport.ru can be seen both as English and as Roman-transliterated Russian cognate word "транспорт" (transport), which is quite plausible because the site itself is in Russian. Many cases of trans-scripting are deliberately playful. For example, the pun name of the flower salon Цвет'ок, meaning "flower", plays on the ambivalence of shared RomanCyrillic graphemes $\langle\mathrm{O}\rangle$ and $\langle\mathrm{K}\rangle$ : the Russian substantive suffix $<-$-оK $>$ is homographic with the English $O K$ and the borrowing " $O \kappa$ " in Russian, thus, additional graphic manipulation through the use of an apostrophe (which is a marker of the English writing system) makes this part of the word ambiguous, or translingual.

When investigating "new Chinglish," Li (2016) explains that "new Chinglish" re-appropriates English in the linguistic practices that used to be associated with "broken English," but are employed nowadays for deliberately created new forms 
to express a range of locally relevant meanings and intentions. It is an "indigenous use of English" (Xu \& Deterding 2017: 126), as in most cases one needs to know Chinese to fully understand the meanings. Unlike Chinese English, "new Chinglish" forms are not intended for international communication and enjoy increasingly positive attitudes "not just among the young and urban elite, but across a much wider spectrum of Chinese society" (Li 2016: 14-15).

The same applies to "new Ruslish," the increasingly frequent translingual manipulation of English-related forms in Russia. Being intended for intranational communication, "new Ruslish" needs to be investigated as a phenomenon related to Ruslish and Russian English, but different from them.

\section{Conclusion}

It is crucially important to spell out what Russian English is and what it is not by looking deeper into various conceptualizations of English-Russian interaction in modern-day intranational communication in Russia. What is referred to as Russian English or Ruslish often differs from the rigorous sociolinguistic treatment of the English language variety actually spoken by Russians, though there might be a good deal of shared forms with or deliberate language play on Russian English distinctive features. That includes the cases defined in this article as "folk Russian English/Ruslish," "mock Russian English/Ruslish," and "new Ruslish." Therefore, two interrelated but separate linguistic phenomena need to be distinguished: Russian English as an EC variety including Ruslish as its basilect on the one hand, and on the other hand, Russian English or Ruslish as a broader language contact concept embracing various cases of English-Russian hybridization and interference, which is closer to its folk metalinguistic treatment.

There is no denying the fact that language contact is "an underlying mechanism for all Englishes" (Onysko 2016: 196). This inevitably leads to certain overlap between different typologies of English varieties and general language contact categorizations. However, the overlap or fuzziness of borders between various contact-induced linguistic outcomes in speech practice and in their theoretical identification cannot be used as an argument for dismissing the idea of Russian English or any other EC variety as a sociolinguistic entity, a generalized linguistic construct characterized by certain distinctive features. I hope that the analysis suggested in this article will contribute to the continuing debate on Expanding Circle Englishes as varieties in their own right.

(C) Alexandra A. Rivlina, 2020

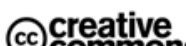




\section{REFERENCES}

Androutsopoulos, Jannis. 2012. 'Greeklish': Transliteration practice and discourse in the context of computer-mediated digraphia. In Alexandra Jaffe, Jannis Androutsopoulos, Mark Sebba \& Sally Johnson (eds.), Orthography as Social Action: Scripts, Spelling, Identity and Power, 359-392. Boston \& Berlin: Walter de Gruyter.

Androutsopoulos, Jannis. 2015. Networked multilingualism: Some language practices on Facebook and their implications. International Journal of Bilingualism 19 (2). 185-205. DOI: $10.1177 / 1367006913489198$

Angermeyer, Phillip S. 2012. Bilingualism meets digraphia: Script alternation and hybridity in Russian-American writing and beyond. In Mark Sebba, Shahrzad Mahootian \& Carla Jonsson (eds.), Language Mixing and Code-switching in Writing, 255-272. New York \& London: Routledge.

Canagarajah, Suresh. 2013. Translingual Practice: Global Englishes and Cosmopolitan Relations. London \& New York: Routledge.

Chun, Elain W. 2004. Ideologies of legitimate mockery: Margaret Cho's revoicings of mock Asian. Pragmatics 14 (2/3). 263-289. DOI: 10.1075/prag.14.2-3.10chu

Creese, Angela \& Adrian Blackledge. 2011. Separate and flexible bilingualism in complementary schools: Multiple language practices in interrelationship. Journal of Pragmatics 43 (5). 1196-1208. DOI: 10.1016/j.pragma.2010.10.006

Crystal, David. 2003. The Cambridge Encyclopedia of the English Language. Cambridge: Cambridge University Press.

Cutler, Cecilia A. 1999. Yorkville crossing: White teens, hip hop and African American English. Journal of Sociolinguistics 3 (4). 428-442. DOI: 10.1111/1467-9481.00089

D’Souza, Jean. 2001. Indian English and Singapore English: Creativity contrasted. In Edwin Thumboo. (ed.), The Three Circles of English: Language Specialists Talk about the English Language, 3-17. Singapore: UniPress.

Fuller, Janet M. 2009. 'Sam need gun go war': Performances of non-Standard English in the construction of identity. Journal of Sociolinguistics 13 (5). 659-669. DOI: $10.1111 / \mathrm{j} .1467-9841.2009 .00420 . x$

García, Ofelia \& Li Wei. 2014. Translanguaging: Language, Bilingualism and Education. Basingstoke: Palgrave Macmillan.

Hill, Jane H. 1998. Language, race, and white public space. American Anthropologist 100 (3). 680-689. DOI: 10.1525/aa.1998.100.3.680

Hill, Jane H. 1999. Styling locally, styling globally: What does it mean? Journal of Sociolinguistics 3 (4). 542-556. DOI:10.1111/1467-9481.00095

Ivleva, Natalya V. 2005. The sublanguage of Russian speaking users of the English language (Ruglish). Innovations and Reproductions in Cultures and Societies. Vienna. URL: http://www.inst.at/irics/speakers_g_m/ivleva.htm.

Jaspers, Jürgen \& Lian M. Madsen. 2016. Sociolinguistics in a languagised world: Introduction. Applied Linguistics Review 7 (3). 235-258. DOI: 10.1515/applirev-2016-0010

Kabakchi, Victor V. 2015. Vtoraya volna biligvizma [The second wave of bilingualism]. Vorto. URL: http://vorto.ru/statyi/vtoraya-volna-bilingvizma.

Lambert, James. 2018. A multitude of "lishes." English World-Wide 39 (1). 1-33. DOI: 10.1075/eww.00001.lam

Lee, Jamie S. 2014. English on Korean television. World Englishes 33 (1). 33-49. DOI: 10.1111/weng.12052

Li, Wei. 2016. New Chinglish and the Post-Multilingualism challenge: Translanguaging ELF in China. Journal of English as a Lingua Franca 5 (1). 1-25. DOI: 10.1515/jelf-20160001 
Li, Wei \& Zhu Hua. 2019: Tranßcripting: playful subversion with Chinese characters. International Journal of Multilingualism 16 (2). 145-161. DOI: 10.1080/14790718. 2019.1575834

Marinova, Elena V. 2013. Teoriya zaimstvovaniya $v$ osnovnykh poniatiyakh i terminakh: Slovar'-spravochnik [Theory of Borrowing in Basic Concepts and Terms: Dictionary and Reference Book]. Moscow: Flinta, Nauka.

Merkulova, Edita N. 2015. "Ay spik from may khart," or does Runglish really exist? Political Linguistics 53 (3). 42-49.

Moody, Andrew. 2009. Englishization in Japanese popular culture: Representation of identity. In Kwok-kan Tam (ed.), Englishization in Asia: Language and cultural issues, 181-206. Hong Kong: Open University of Hong Kong Press.

Moody, Andrew \& Yuko Matsumoto. 2012. Lu-go and the role of English loanwords in Japanese: The making of a 'pop pidgin.' In Jamie S. Lee \& Andrew Moody (eds.), English in Asian popular culture, 103-126. Hong Kong: Hong Kong University Press.

Niedzielski, Nancy A. \& Dennis R. Preston. 2000. Folk Linguistics. Berlin \& New York: Mouton de Gruyter.

Onysko, Alexander. 2016. Modeling world Englishes from the perspective of language contact. World Englishes 35 (2). 196-220.

Pankin, Vyacheslav M. \& Andrey V. Filippov. 2011. Iazykovye kontakty: Kratkij slovar' [Language contacts: Concise dictionary]. Moscow: Flinta, Nauka.

Pennycook, Alastair. 2003. Global Englishes, Rip Slyme, and performativity. Journal of Sociolinguistics 7 (4). 513-533. DOI: 10.1111/j.1467-9841.2003.00240.x

Proshina, Zoya G. 2019. Elaborating on the Expanding Circle. World Englishes 38 (1-2). 233 244. DOI: $10.1111 /$ weng. 12371

Proshina, Zoya G. 2020. Russian Englishes. In Cecil L. Nelson, Zoya G. Proshina \& Daniel R. Davis (eds.), The Handbook of World Englishes. $2^{\text {nd }}$ edn, 232-247. Malden, MA \& Oxford, UK: Blackwell.

Proshina, Zoya G. \& Anna A. Eddy (eds.). 2016. Russian English: History, Functions, and Features. Cambridge: Cambridge University Press.

Proshina, Zoya G. \& Alexandra A. Rivlina. 2018. Mock Russian English: Playful and parodic use of the Russian variety of English in the Inner Circle countries. Moscow State University Bulletin. Series 19. Linguistics and Intercultural Communication 3. 18-30.

Rivlina, Alexandra A. 2015. Bilingual creativity in Russia: English-Russian language play. World Englishes 34 (3). 436-455. DOI: 10.1111/weng.12153

Rivlina, Alexandra A. 2016. Global English-related digraphia and Roman-Cyrillic biscriptal practices. Procedia - Social and Behavioral Sciences. 236, 207-212. DOI: 10.1016/j.sbspro.2016.12.006

Rivlina, Alexandra A. 2017. Global English-local digraphia: Translingual aspect. RUDN Journal of Language Education and Translingual Practices 14 (2). 171-180. DOI: 10.22363/2312-80K11-2017-14-2-171-180 (In Russ).

Rivlina, Alexandra A. 2020. Bilingual language play and world Englishes. In Cecil L. Nelson, Zoya G. Proshina \& Daniel R. Davis (eds.), The Handbook of World Englishes. $2^{\text {nd }}$ edn., 407-429. Malden, MA \& Oxford, UK: Blackwell Publishing.

Schneider, Edgar W. 2012. English around the World: An introduction. Cambridge: Cambridge University Press. DOI: 10.1111/weng.12204

Schneider, Edgar W. 2016. Hybrid Englishes: An exploratory survey. World Englishes 35 (3). 339-354. DOI: 10.1111/weng.12204.

Spilioti, Tereza. 2019. From transliteration to trans-scripting: Creativity and multilingual writing on the internet. Disourse, Context \& Media 29. URL: https://www.sciencedirect.com/science/article/pii/S2211695818303180. 
Tarone, Elaine. 2018. Interlanguage. The Encyclopedia of Applied Linguistics. Wiley Online Library. DOI: 10.1002/9781405198431.wbea10561.pub2.

$\mathrm{Xu}$, Zhichang \& David Deterding. 2017. The playfulness of 'new' Chinglish. Asian Englishes 19 (2). 116-127. DOI: 10.1080/13488678.2017.1292445

Zemskaia, Elena A., Margarita V. Kitaigorodskaia \& Nina I. Rozanova. 1994. Yazykovaia igra [Language play]. In Elena A. Zemskaia (ed.), Russkaia razgovornaia rech' [Russian Informal Speech], 172-214. Moscow: Nauka.

\section{Internet Resources}

Cole, Laine R. 2010. Babes and babushkas: It's Russian English month! The MacMillan Dictionary Blog. URL: http://www.macmillandictionaryblog.com/babushka-russianenglish-month.

Dolgov, Anna. 2015. Putin gives sports minister English coursebook for birthday. The Moscow Times. URL: https://themoscowtimes.com/news/putin-gives-sports-minister-englishcoursebook-for-birthday-48338.

Epstein, Mikhail. 2006. Dar slova [Gift of language]. Ezhenedelnyi Leksikon ot Mikhaila Epshteina [Weekly Lexicon from Mikhail Epstein]. URL: https://subscribe.ru/ archive/linguistics.lexicon/200609/24203244.html.

Khudyakova, Tatyana. 2018. Sindrom Braitona: kak runglish stal yazykom emmigratsii [The Brighton syndrome: How Runglish became the language of Russian emigration]. Skyeng Magazine. URL: https://magazine.skyeng.ru/sindrom-brajtona.

Kuznetsov, Alexandr. 2012. Russkii, a ne "ruslish" [Russian, not "Ruslish"]. Moskovskii Komsomolets. URL: http://www.mk.ru/blogs/posts/russkiy-a-ne-ruslish.html.

Mostitskiy, Igor. 2012. Universalnyi dopolnitelnyi prakticheskiy tolkovyi slovar' [Universal supplemental practical Russian-Russian dictionary]. URL: https://mostitsky_ universal.academic.ru/4771.

Nicholls-Lee, Deborah. 2018. English is no longer a foreign language in NL, but it has a unique character here. DutchNews.nl. URL: https://www.dutchnews.nl/features/2018/01/englishis-no-longer-a-foreign-language-in-the-netherlands-but-it-has-a-unique-character-here.

Nikitin, Dmitry. 2009. Do you speak Ruslish? The Dmitry Nikitin Blog. URL: http://nikitindima.name/do-you-speak-ruslish.

Novosyolova, Elena. 2013. Mat' Kuz'my: Professiya perevodchika v krizise [Kuzma's mother: Professional interpreting in crisis]. Rossiiskaya Gazeta. URL: https://rg.ru/2013/02/19/ perevod.html.

Partanenko, Valeriya. 2016. Lukhari - eto chto takoe? [Lukhari - what is it?]. FB.ru. URL: https://fb.ru/article/265312/luhari---eto-chto-takoe.

"Ruslish:" ofitsialnyi yazyk MKS ["Ruslish:" the official language of the ISS (International Space Station)]. 2019. Mir 24. URL: https://mir24.tv/news/14498805/ruslish-oficialnyiyazyk-mks.

Russian National Corpus. 2019. URL: http://ruscorpora.ru/new/en.

Vorobyevskii, Yuriy. 2017. Vavilon [Babylon]. Pravoslavnaya Beseda, Apr. 19. URL: https://p-beseda.ru/publication/75744c3a-2509-11e7-afa1-cf78c57154ad.

Wikipedia. 2019. Runglish. URL: https://en.wikipedia.org/wiki/Runglish.

Woolcot, Simon. 2015. That is another cook; How to speak English like Louis van Gaal. Follow the adventures of Amsterdam's shallowest man. URL: https://amsterdamshallowman.com/2015/02/another-cook-speak-english-like-louis-vangaal.html. 


\section{Article history:}

Received: 15 January 2020

Revised: 13 July 2020

Accepted: 15 July 2020

\section{История статьи:}

Дата поступления в редакцию: 15 января 2020

Дата принятия к печати: 15 июля 2020

\section{Bionote:}

Alexandra A. RIVLINA is a Candidate in Philology, Associate Professor of School of Foreign Languages, National Research University Higher School of Economics in Moscow. Her research interests include language contact, World Englishes, and EnglishRussian interaction. She is a member of the International Association for World Englishes (IAWE) since 2010. She contributed to the edited books Russian English: History, Functions, and Features (Cambridge University Press, 2016), The Handbook of World Englishes (Wiley-Blackwell Publ., 2nd edn., 2020) and the journal World Englishes.

\section{Contact information:}

School of Foreign Languages, National Research University Higher School of Economics, 20 Myasnitskaya Ulitsa, Moscow, 101000, Russia

e-mail: rivlina@mail.ru; arivlina@hse.ru

ORCID ID: 0000-0002-9772-3349

\section{Сведения об авторе:}

Александра Абрамовна РИВЛИНА - кандидат филологических наук, доцент Школы иностранных языков Национального исследовательского университета «Высшая школа экономики» (Москва). Научные интересы: языковые контакты, контактная вариантология английского языка, взаимодействие русского языка с английским. Член Международной ассоциации исследователей вариантов английского языка (IAWE) с 2010 г. Среди ее публикаций - главы в коллективных монографиях Russian English: History, Functions, and Features (Cambridge University Press, 2016) и The Handbook of World Englishes (Wiley-Blackwell Publ., 2nd edn., 2020), статьи в журнале World Englishes.

\section{Контактная информация:}

Национальный исследовательский университет «Высшая школа экономики» 101000, Москва, ул. Мясницкая, 20 e-mail: rivlina@mail.ru; arivlina@hse.ru

ORCID ID: 0000-0002-9772-3349 